\title{
TREATMENT OF THORACOLUMBAR MULTIPLE FRACTURES WITH MINIMALLY INVASIVE SURGERY
}

\author{
TRATAMENTO DE FRATURAS TÓRACO-LOMBARES MÚLTIPLAS COM CIRURGIA \\ MINIMAMENTE INVASIVA \\ TRATAMIENTO DE LAS FRACTURAS TORACOLUMBARES MÚLTIPLES CON CIRUGÍA \\ MÍNIMAMENTE INVASIVA
}

Felix Dolorit Verdecia ${ }^{1}$, Hiram Martínez Medina²

1. International Neurosurgery Institute, Larkin Hospital, Miami, Florida, USA

2. G/G Centro Internacional de Neurocirugía, 6140 SW 70 ST 2do floor South Miami, FL 33143

\begin{abstract}
Objective: To demonstrate that the extrapedicular unilateral percutaneous treatment in multiple thoracolumbar fractures is effective, minimally invasive and can treat several vertebrae at the same time in the same surgery. Method: From January 2007 to January 2015306 patients with multiple vertebral fractures in the thoracolumbar junction of various etiologies were treated, of which 246 were women and 60 men. Results: The extrapedicular unilateral treatment shows good clinical results that are maintained over time, is performed on an outpatient basis with minimal complications, and enables rapid incorporation of patients to their daily activities. Conclusions: Our study shows that unilateral extrapedicular percutaneous kyphoplasty is an effective treatment for multiple thoracolumbar vertebral fractures. This method makes the procedure less invasive, allowing multiple levels are treated in the same surgical intervention, resulting in relief of pain and stability of the spine, minimal complications and immediate return of the patient to daily activities.
\end{abstract}

Keywords: Minimally invasive surgical procedures; Spinal fractures; Thoracic vertebrae; Lumbar vertebrae.

RESUMO

Objetivo: Demonstrar que o tratamento percutâneo unilateral extrapedicular em fraturas tóraco-lombares múltiplas é eficaz, minimamente invasivo e que é possível tratar várias vértebras de uma vez na mesma cirurgia. Método: No período de janeiro de 2007 a janeiro 2015 foram tratados 306 pacientes com diagnóstico de fraturas vertebrais múltiplas na junção tóraco-lombar de várias etiologias, dos quais 246 eram mulheres e 60 homens. Resultados: O tratamento unilateral extrapedicular mostra bons resultados clínicos que se mantêm ao longo do tempo, é realizada em ambulatório, com o mínimo de complicações e permite a incorporação rápida do paciente às suas atividades diárias. Conclusões: Nosso estudo mostra que a cifoplastia unilateral extrapedicular percutânea é um tratamento eficaz para fraturas vertebrais tóraco-lombares múltiplas. Este método torna o procedimento menos invasivo, permitindo que múltiplos níveis sejam tratados na mesma intervenção cirúrgica, obtendo-se alívio da dor e estabilidade da coluna vertebral, o mínimo de complicações e retorno imediato do paciente às atividades diárias.

Descritores: Procedimentos cirúrgicos minimamente invasivos; Fraturas da coluna vertebral; Vértebras torácicas; Vértebras lombares.

\section{RESUMEN}

Objetivo: Demostrar que el tratamiento percutáneo unilateral extrapedicular en las fracturas toracolumbares múltiples es efectivo, mínimamente invasivo y que se pueden tratar varias vértebras a la vez en la misma cirugía. Método: En el período de enero de 2007 a enero de 2015 se trataron 306 pacientes con el diagnóstico de fracturas vertebrales múltiples de la unión toracolumbar de diversas etiologías, de los cuales 246 fueron mujeres y 60 hombres. Resultados: El tratamiento unilateral extrapedicular muestra buenos resultados clínicos mantenidos en el tiempo, se realiza de forma ambulatoria, con mínimas complicaciones, y permite una rápida incorporación de los pacientes a sus actividades diarias. Conclusiones: Nuestro estudio muestra que la cifoplastia unilateral extrapedicular por vía percutánea es un tratamiento efectivo para las fracturas vertebrales toracolumbares múltiples. Este método hace al procedimiento menos invasivo, permitiendo tratar múltiples niveles en una misma intervención quirúrgica, logrando alivio del dolor y la estabilidad de la columna vertebral, mínimas complicaciones y una inmediata incorporación del paciente a sus actividades diarias.

Descriptores: Procedimientos quirúrgicos mínimamente invasivos; Fracturas de la columna vertebral; Vértebras torácicas; Vértebras lumbares.

\section{INTRODUCTION}

Spinal fractures are a big health problem, with approximately 700,000 new cases each year in the United States, 280,000 of which cause intense pain and 150,000 of which require hospitalization. More than $25 \%$ of North American women older than 50 years of age will suffer one or more vertebral fractures secondary to osteoporosis. Worldwide, a new spinal fracture occurs every 22 seconds. ${ }^{1-3}$ 
The spine is the most common site of bone metastasis, at $69 \%$. Around $70 \%$ of metastatic lesions are located in the thoracolumbar region. ${ }^{4}$ The thoracolumbar junction is characterized as being biomechanically vulnerable, i.e., it is more susceptible to developing instability following any damage, whether traumatic, tumoral, or degenerative in origin. On the other hand, it is a fact that vertebral fractures in this region lead to progressive dorsal kyphosis that can increase mortality by from $23 \%$ to $35 \%$, reduce vital respiratory capacity by $9 \%$ for each dorsal vertebra fractured, accelerate the sensation of fullness following meals, and increase the level of depression. Many of these patients become dependent and can be relegated to a wheelchair or a bed in the not too distant future. .-7 $^{5-1}$

The planning of surgical treatment of this location should have these objectives: pain relief, prevention of neurological deficit, restoration of spinal stability, and improvement of the quality of life.

The role of surgery in the treatment of spinal fractures is controversial. While techniques based on postural reduction and rest have remained virtually unchanged, surgical treatment has experienced constant renovation. This has been the result of three basic elements.

One: better knowledge of the biomechanics and kinetics of the spine that has allowed the adoption of different solutions to the classic problems of instability. Two: increasingly sophisticated advances in diagnostic tools. Three: major advances in instrumentation devices, materials, and spine support techniques that have made fantastic methods of lesion repair available to us, as is the case with balloon kyphoplasty. ${ }^{8}$

The objective of our study is to demonstrate that, differently from many authors who perform bilateral transpedicular kyphoplasty, the unilateral extrapedicular approach is a less invasive method that permits treating multiple levels in the same surgical procedure with few complications and that provides continued pain relief and improved quality of life to patients over time.

\section{MATERIAL AND METHODS}

The study sample was made up of 306 patients diagnosed with multiple spine fractures of the thoracolumbar junction of various etiologies, treated at the International Institute of Larkin Hospital in Miami, Florida, during the period from January 2007 to January 2015. Two hundred and forty-six of them were women between 45 and 93 years of age. Informed consent was obtained from all patients and the protocol to be followed was explained to them.

The diagnosis was based on a thorough physical exam supported by simple AP and lateral view x-rays, computed axial tomography with three-dimensional image reconstruction, especially in the STIR sequence that clearly shows edema that appears as hyper intense in an acute fracture with compression..$^{9,10}$

A decision for surgical treatment was always preceded by failed conservative management where the primary clinical symptom was difficult-to-control pain of long evolution and progressive intensity, exacerbated when in a standing position and hindering the patient's ability to walk, forcing bed rest.

An evaluation of pain was conducted in all cases using the Visual Analog Scale (VAS) and of functional quality using the Oswestry scale ${ }^{11}$ prior to surgery, immediately following surgery, after one month, six months, and then yearly with support by telephone or in-home visits. To perform the kyphoplasty, we used the Kyphon system from Medtronic (Figure 1), Kyphon System (Figure 2) with fluoroscopy.

The patient was placed in a prone position on the operating table to achieve the extension of the thoracic and lumbar spines, and the planning of the approach was conducted by fluoroscopy. (Figure 3) In most patients, local anesthesia and sedation were sufficient, although in some cases, due to their health condition, we preferred to use general anesthesia.

Once the entry points were defined, the skin was numbed with lidocaine and a $2 \mathrm{~mm}$ incision was made for the introduction of the cannulated needle, (Figure 4) though which we introduced a drill with which we created a space in the vertebral body. At this time, a sample was taken to perform a biopsy. The drill was removed and balloons that have radiopaque markers were introduced in order to achieve precise placement.

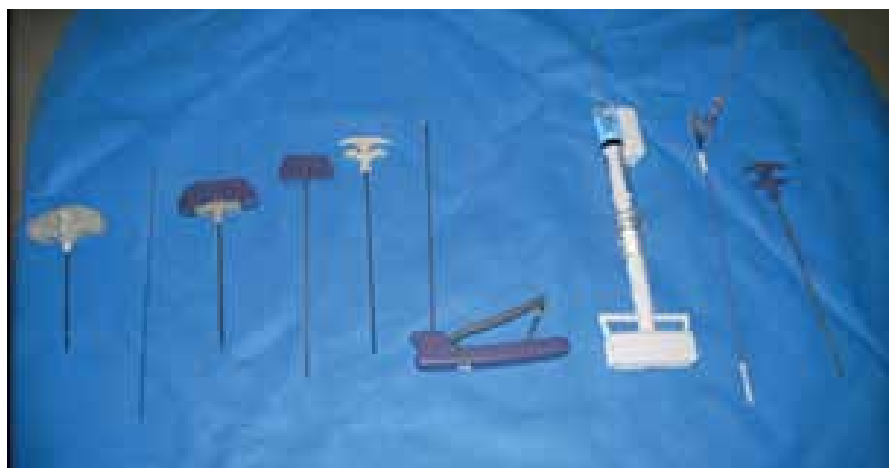

Figure 1. Kyphon System

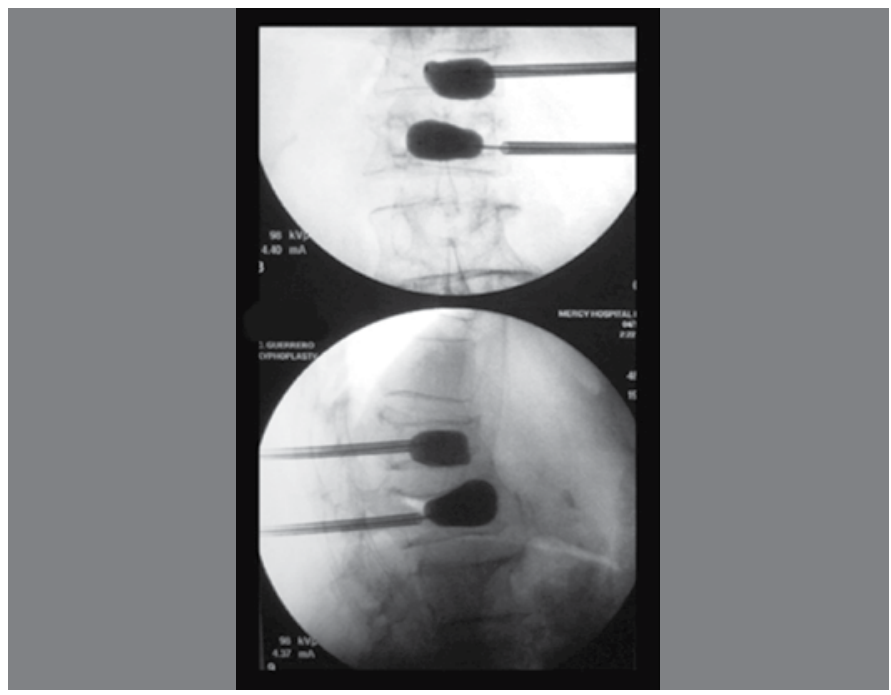

Figure 2. Fluoroscopy

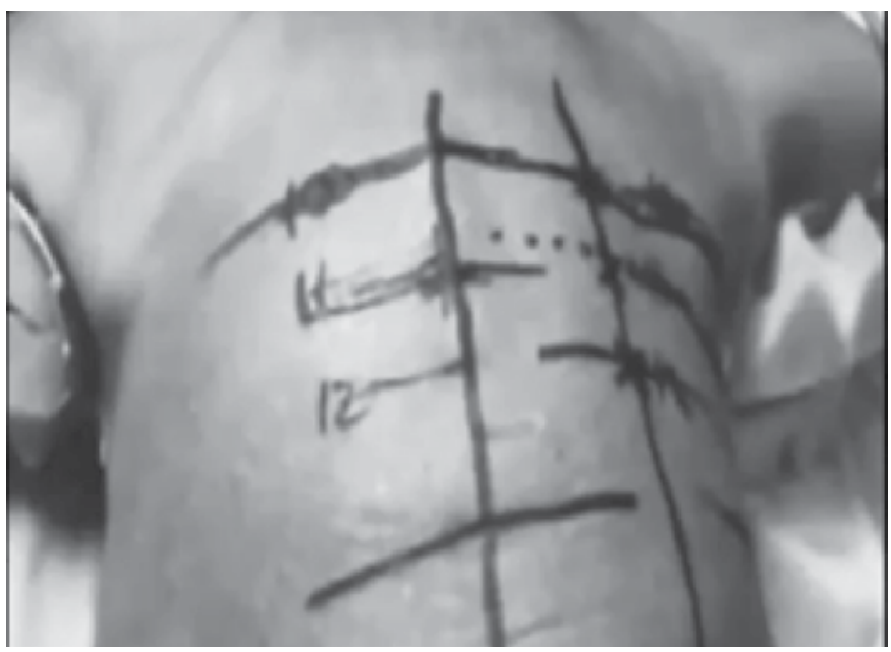

Figure 3. Planning.

The balloon was inflated using a contrast injection system with a volume of 4 to $5 \mathrm{ml}$ and a maximum pressure of 300 psi. The balloon remained inflated for between 4 and 5 minutes, after which time it was deflated and removed. Then, using a device also introduced through the cannula, the PMMA was injected under low pressure. In our experience, we used Kyph ${ }^{\circledR} \mathrm{HV}$-R bone cement. After waiting for five minutes, the cannula was removed and the small wound closed with Dermabond.

As regards data processing and analysis, we input the data into a percentage system where they were converted to statistical tables. 


\section{RESULTS}

In our study sample, there was predominance of female patients (80.4\%) as well as of patients older than 60 years of age $(82.7 \%)$. It should be noted that 11 of the patients treated were older than 90 years of age. (Figures 5 and 6 )

In terms of the causes treated, most cases were from osteoporosis $(87.25 \%)$ followed by metastasis (9.8\%). (Figure 7)

In terms of the location of the fractures, the thoracolumbar junction was the most affected at $53.6 \%$ and the number of levels most often affected and treated in one procedure was 2 levels (67.65\%). It is significant that 17 patients (5.55\%) were treated at more than 3 levels. (Figures 8 and 9 ) Most of the fractures were treated within two months of the occurrence, representing $81.4 \%$.

Most of the procedures were performed as outpatient $(91.8 \%)$ and follow-up of the evolution continued for more than two years in $71.6 \%$ of the cases. (Figures 10 and 11)

Regarding functional capacity, we achieved a reduction from $81.6 \%$ prior to surgery to $19.3 \%$ at four years of follow-up. We used the Oswestry scale (Figure 12) to measure this indicator. In terms of the behavior of pain, there was no relief in only 5 cases, which represents 1.63\%. (Figure 13) We also measured the VAS, which decreased from $88.3 \%$ prior to surgery to only $15.4 \%$ at the end of 4 years of follow-up. (Figure 14) Spinal stability was achieved in $81 \%$ (Figure 15) and we encountered only 12 complications, for a low $3.9 \%$, although none of them had any clinical impact. (Figure 16)

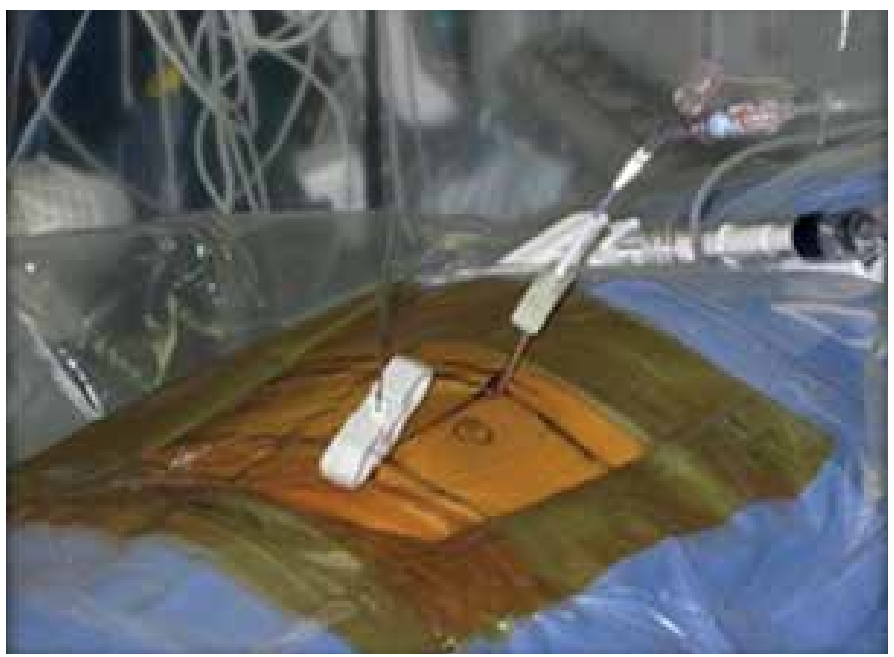

Figure 4. Introduction of the cannula.

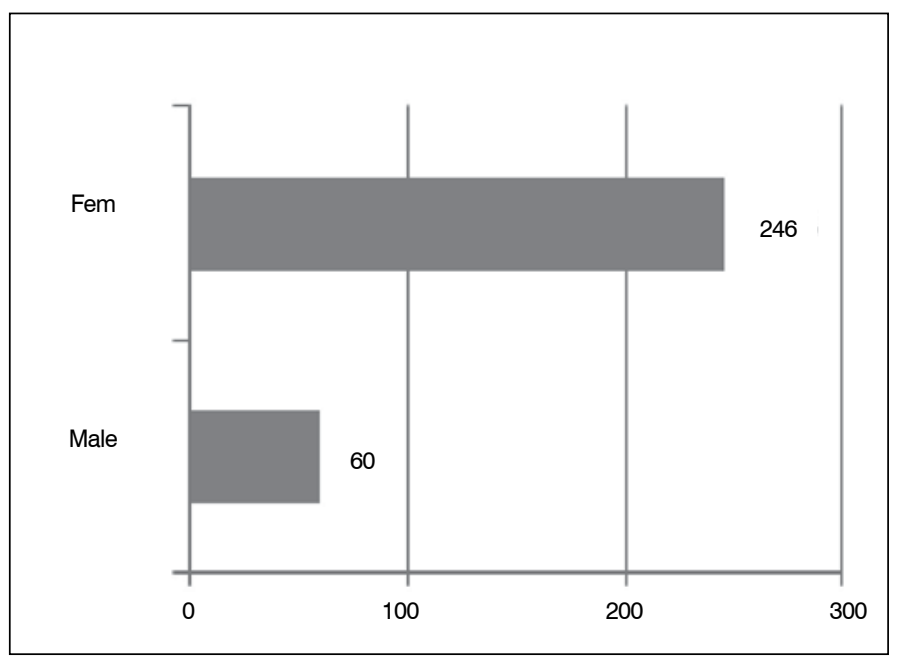

Figure 5. Distribution by sex.

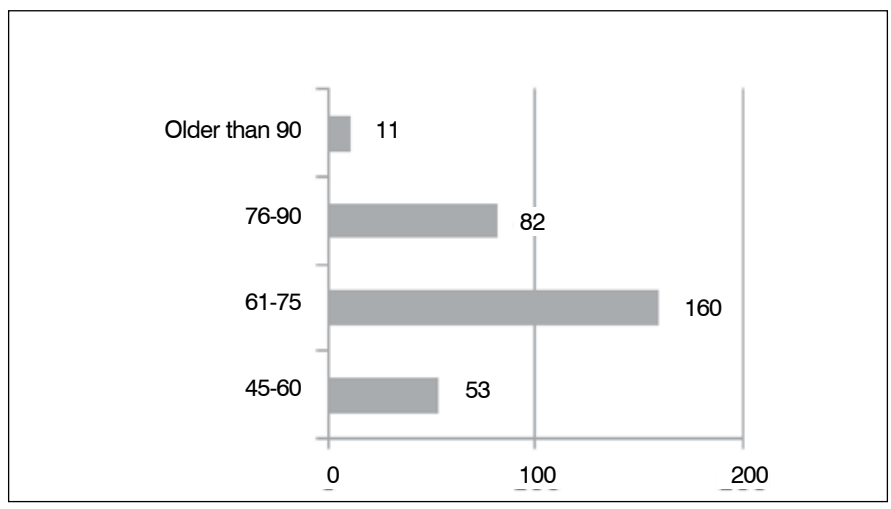

Figure 6. Distribution by age.

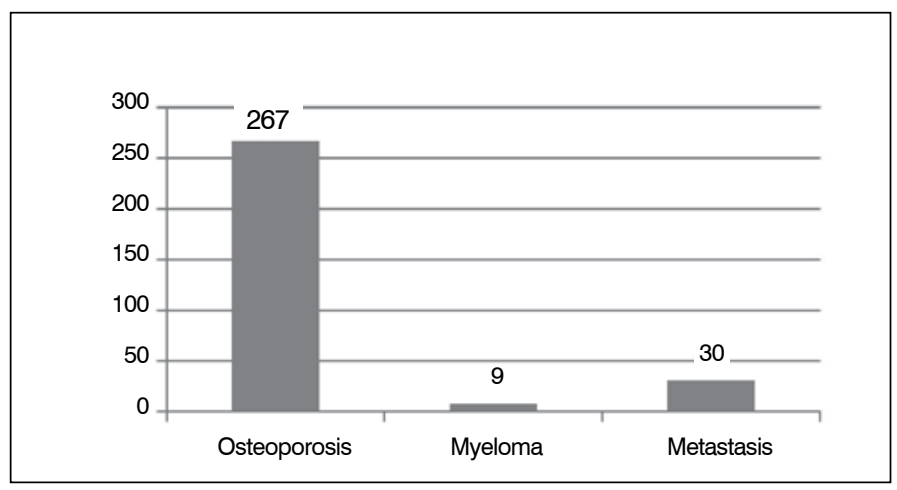

Figure 7. Distribution by etiology of the fracture.

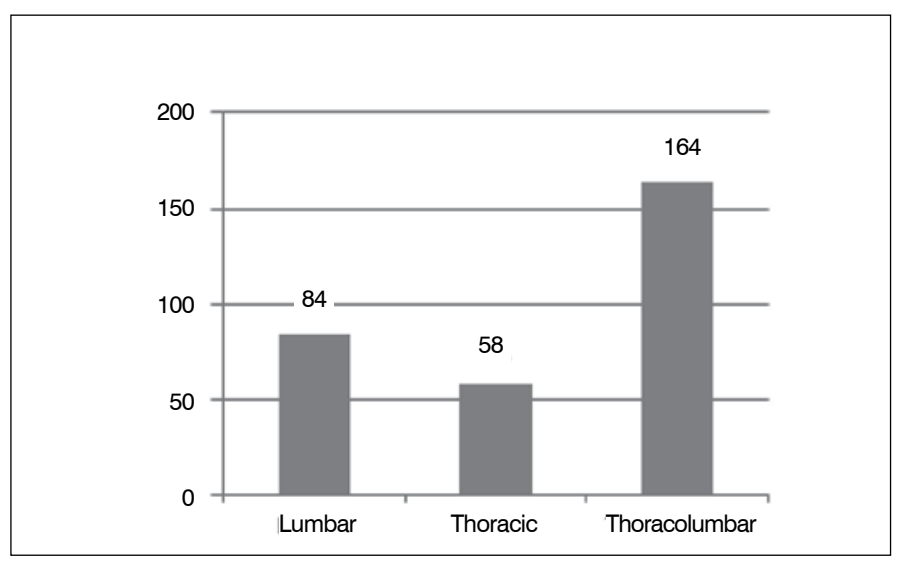

Figure 8. Location of the fractures.

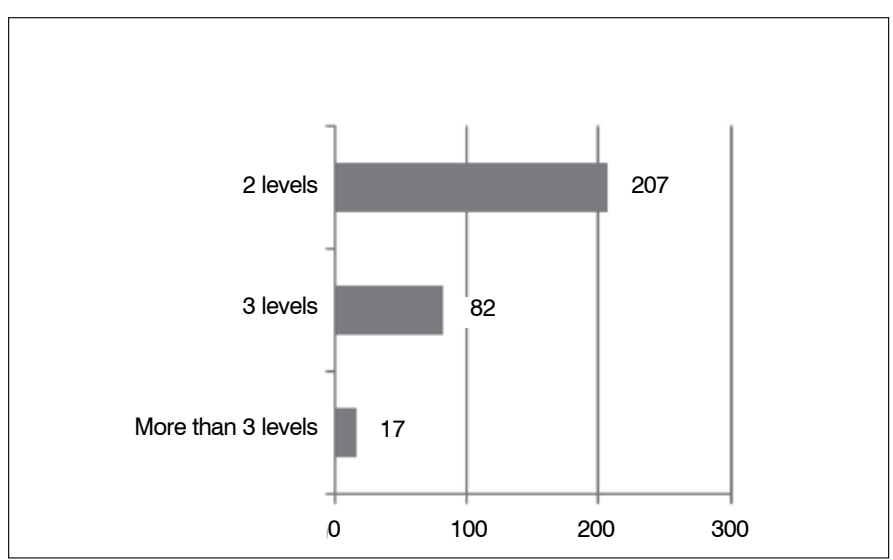

Figure 9. Number of levels affected. 


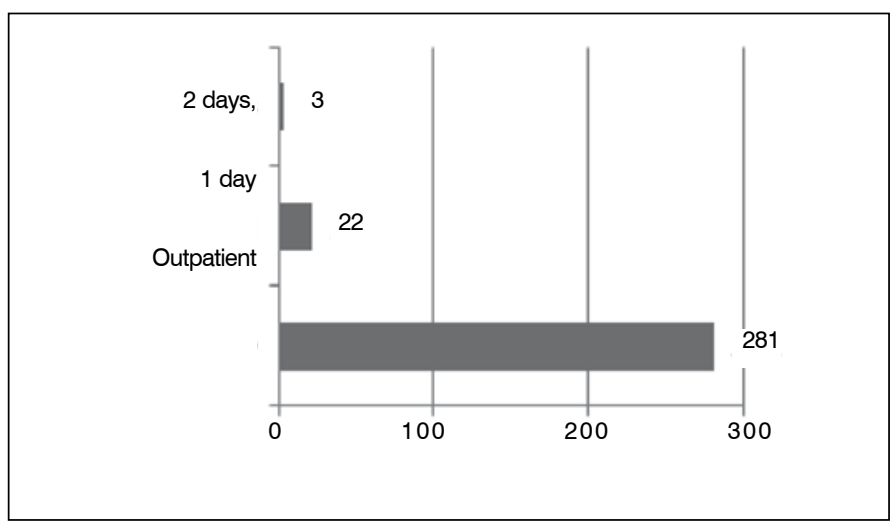

Figure 10. Hospital stay.

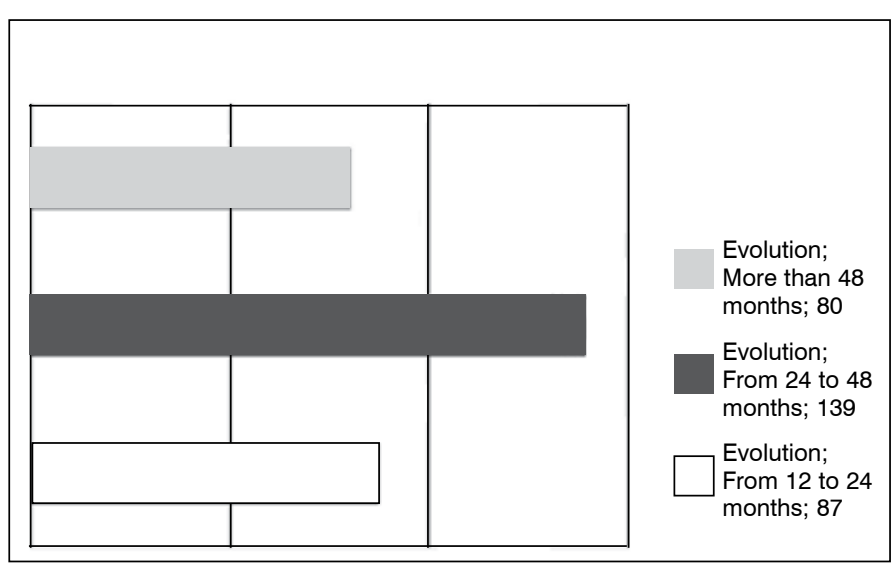

Figure 11. Follow-up of the evolution.

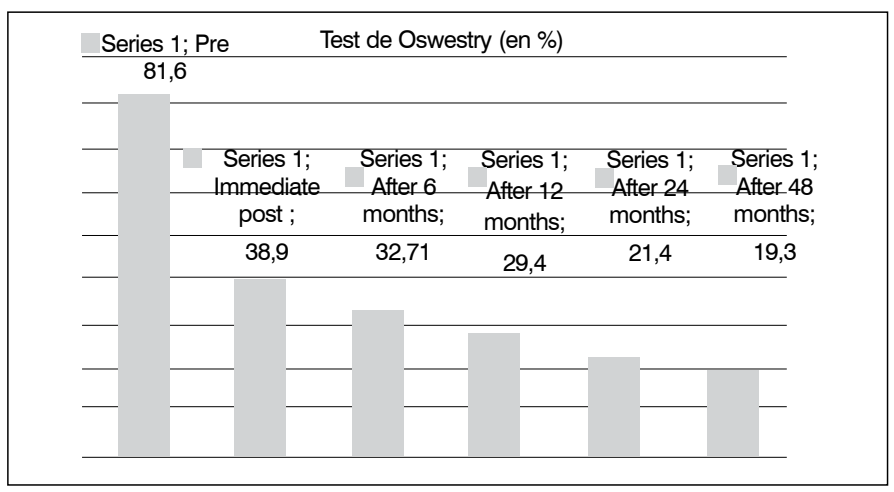

Figure 12. Oswestry Test.

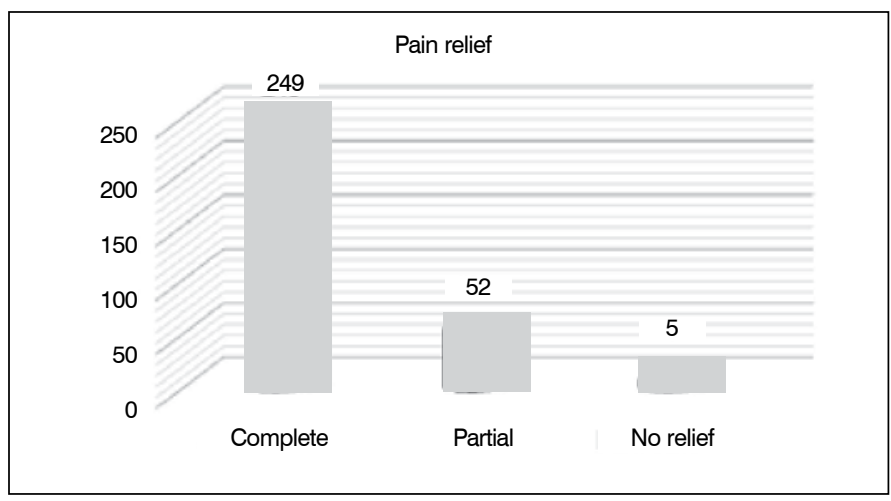

Figure 13. Pain relief behavior.

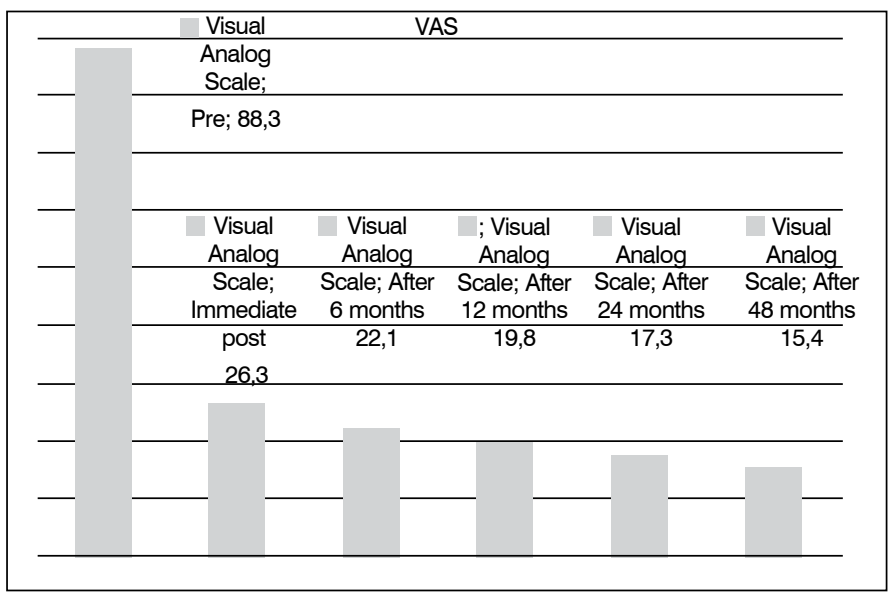

Figure 14. Visual Analog Scale

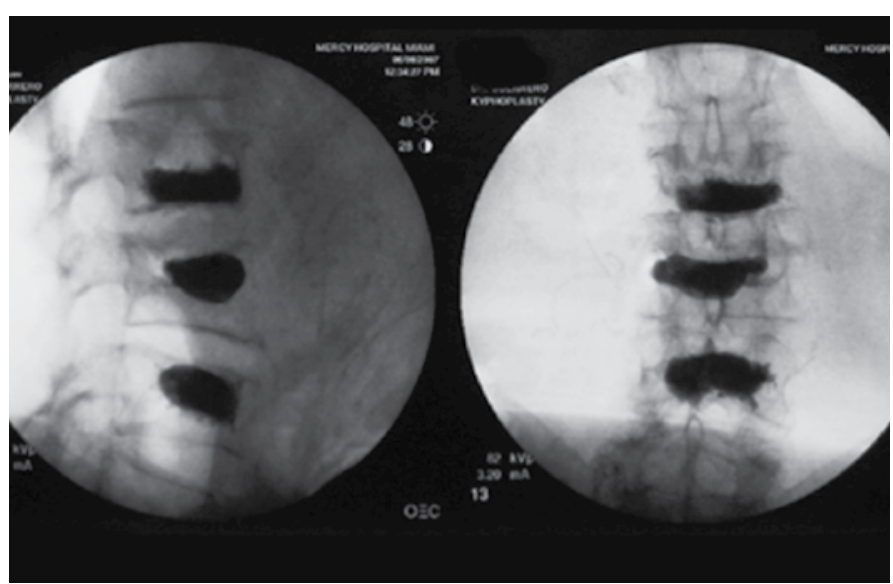

Figure 15. Stable spine

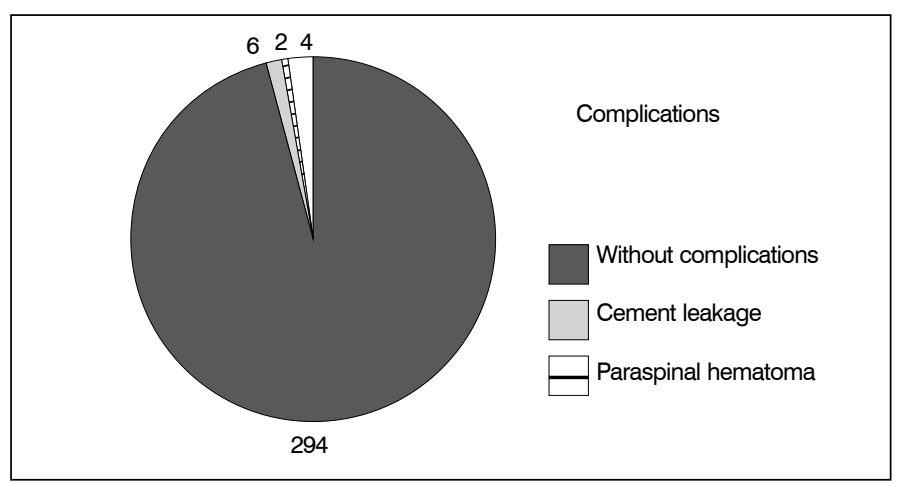

Figure 16. Complications.

\section{DISCUSSION}

Surgery for vertebral fractures of the thoracolumbar spine has undergone a significant evolution mostly due to the enormous developments in radiology techniques, the intense research conducted about the biomechanics and kinetics of the spine, as well as to the new spine restoration materials, where balloon kyphoplasty plays a very important role..$^{12,13}$

Most of the studies reviewed perform this procedure bilaterally via transpedicular approach.

Regardless of the location of the fracture, we propose using the unilateral extrapedicular technique, in which the point of entry is immediately superior and lateral to the pedicle, medial to the head of the rib (and sometimes through the head of the rib) in the dorsal location. If the 
entry point is very lateral, the lung cavity may be perforated, and if it is very low, the segmental artery may be affected. ${ }^{14}$

The explanation for the predominance of women above 60 years of age could be due to the fact that the most frequent causes of idiopathic osteoporosis are advanced age and menopause. The latter affects $35 \%$ of women older than 50 years of age and $50 \%$ of women older than 75 years of age..$^{15}$

Our study was conducted in Miami, Florida and it is known that 25\% of North American women above 50 years of age suffer from one or more vertebral fractures secondary to osteoporosis. ${ }^{16}$ Additionally, the second most common cause in our series was metastasis. It is also known that the tumor that most often metastasizes to the vertebrae is primary breast cancer, ${ }^{17}$ that largely justifies our results.

In agreement with reports by other authors, the most affected region in our study was the thoracolumbar spine. ${ }^{18}$

At first, it was thought that the ideal patient to undergo this type of procedure was that who suffered pain secondary to a fracture that persisted for more than 4 to 6 weeks. Although a rule cannot be established, better recovery at this level of the spine is achieved the earlier the treatment is performed. ${ }^{19,20}$ Hence a large percentage of our cases were treated earlier.According to reports from other researchers, the procedure can be performed as outpatient, ${ }^{21}$ which was fully confirmed by our study. With the help of telephone calls and home visits, we provided follow-up for more than two years with most of our patients.

Kyphoplasty is an optimal technique for the treatment of pathological fractures. The rapid improvement of pain maintained over time, as well as the functional recovery of the patients, make it a perfectly valid technique. ${ }^{22,23}$

Our study showed that according to what has been mentioned above, we could provide pain relief and a return to normal work, in addition to good spine stability, results that have all been maintained over time In a multicenter report of 1439 patients with 2194 fractures treated through kyphoplasty, the percentage of serious complications reached $0.2 \%{ }^{24}$ Equivalent or very comparable results were achieved in our study.

\section{CONCLUSION}

Our study shows that percutaneous unilateral extrapedicular kyphoplasty is an effective treatment for multiple thoracolumbar fractures from pathological causes. It proved to be a safe method for patient pain relief and improved functional capacity maintained over time, with few complications. This much less invasive procedure reduces surgery time per level and permits multilevel treatment in the same surgical intervention.

\section{ACKNOWLEDGEMENTS}

To my entire work team and to the group of the International Neurosurgery Institute of the Larkin Hospital in Miami, Florida.

All the authors declare that there are no potential conflicts of interest regarding this article.

\section{REFERENCES}

1. Garfin SR, Reilley MA. Minimally invasive treatment of osteoporotic vertebral body compression fractures. Spine J. 2002;2(1):76-80.

2. Myers ME. Vertebroplasty and kyphoplasty: is one of these procedures the best choice for all patients? AJNR Am J Neuroradiol. 2004;25(7):1297.

3. Wu SS, Lachmann E, NaglerW. Current medical, rehabilitation, and surgical management of vertebral compression fractures. J Womens Health (Larchmt). 2003;12(1):17-26.

4. Siegal T, Siegal T. Surgical decompression of anterior and posterior malignant epidural tumors compressing the spinal cord: a prospective study Neurosurgery. 1985:17(3):424-32.

5. Belkoff SM, Mathis JM, Fenton DC, Scribner RM, Reiley ME, Talmadge K. An ex vivo biomechanical evaluation of an inflatable bone tamp used in the treatment of compression fracture. Spine (Phila Pa 1976). 2001:26(2):151-6.

6. Hardouin P, Fayada P, Leclet H, Chopin D. Kyphoplasty. Joint Bone Spine. 2002;69(3):256-61.

7. Leidig G, Minne HW, Sauer P, Wüster C, Wüster J, Lojen M, et al. A study of complaints and their relation to vertebral destruction in patients with osteoporosis. Bone Miner. 1990:8(3):217-29

8. Martinez-Quiñones JV, Aso-Escario J, Arregui-Calvo YR. Percutaneous vertebral augmentation: vertebroplasty and kyphoplasty: operative technique. Neurocirugia (Astur). 2005;16(5):427-40.

9. Baker LL, Goodman SB, Perkash I, Lane B, Enzmann DR. Benign versus pathologic compression fractures of vertebral bodies: assessment with conventional spin-echo, chemical-shift, and STIR MR imaging. Radiology. 1990;174(2):495-502.

10. Blumenkopf B. Radiology and anatomy of lumbar and lumbosacral fractures. In: Rea G, Miller C, editors. Spinal trauma: current evaluation and management. Neusosurgical topics. USA: AANS; 1993. p. 157-63.

11. Roland $\mathrm{M}$, Fairbank J. The roland-morris disability questionnaire and the oswestry disability questionnaire. Spine (Phila Pa 1976). 2000;25(24):3115-24.

12. Phillips FM. Minimally invasive treatments of osteoporotic vertebral compression fractures. Spine (Phila Pa 1976). 2003;28(Suppl 15):S45-53

13. Teng MM, Wei CJ, Wei LC, Luo CB, Lirng JF, Chang FC, et al. Kyphosis correction and height restoration effects of percutaneous vertebroplasty. AJNR Am J Neuroradiol. 2003;24(9):1893-900
14. Martínez Quiñones JV Aso J, Arregui R. Tratamiento de las fracturas dorsolumbares agudas no osteoporóticas mediante cifoplastia. Tres años de experiencia. In: XX Congreso Nacional de la Sociedad GEER, Valladolid, 2 e 3 de junio, 2006.

15. Felsenberg D, Silman AJ, Lunt M, Armbrecht G, Ismail AA, Finn JD, et al. Incidence of vertebral fracture in europe: results from the European Prospective Osteoporosis Study (EPOS). J Bone Miner Res. 2002;17(4):716-24.

16. Uppin AA, Hirsch JA, Centenera LV, Pfiefer BA, Pazianos AG, Choi IS. Occurrence of new vertebral body fracture after percutaneous vertebroplasty in patients with osteoporosis. Radiology. 2003;226(1):119-24.

17. Sundaresan N, Steinberger AA, Moore F, Arginteanu M. Surgical management of primary and metastatic tumors of the spine. In: Schmideck HH, editors. Schmideck \& Sweet operative neurosurgical techniques: indications, methods and results. 4th ed. Philadelphia: Saunders; 2000. p. 2146-70

18. Holdsworth F. Fractures, dislocations, and fracture-dislocations of the spine. J Bone Joint Surg Am. 1970;52(8):1534-51.

19. Heini PF, Orler R. Kyphoplasty for treatment of osteoporotic vertebral fractures. Eur Spine J. 2004;13(3):184-92

20. Lieberman IH, Dudeney S, Reinhardt MK, Bell G. Initial outcome and efficacy of "kyphoplasty" in the treatment of painful osteoporotic vertebral compression fractures. Spine (Phila Pa 1976). 2001;26(14):1631-8.

21. Mathis JM, Barr JD, Belkoff SM, Barr MS, Jensen ME, Deramond H. Percutaneous vertebroplasty: a developing standard of care for vertebral compression fractures. AJNR Am J Neuroradiol. 2001;22(2):373-81.

22. Ledlie JT, Renfro MB. Kyphoplasty treatment of vertebral fractures: 2-year outcomes show sustained benefits. Spine (Phila Pa 1976). 2006:31(1):57-64.

23. Center JR, Nguyen TV, Schneider D, Sambrook PN, Eisman JA. Mortality after all major types of osteoporotic fracture in men and women: an observational study. Lancet. 1999;353(9156):878-82.

24. Garfin SR, Lin G, Lieberman I, Phillips F, Truumees E. Retropective analysis of the outcomes of balloom kyphoplasty to treat vertebral body compression fracture (VCF) refractory to medical management. Eur Spine J. 2001;10:S7-S8. 